九州大学学術情報リポジトリ

Kyushu University Institutional Repository

\title{
日本における極低出生体重児の気管切開に関する全 国調査
}

倉田，浩昭

http://hdl. handle. net/2324/4060262

出版情報: Kyushu University，2019，博士（医学），論文博士 バージョン：

権利関係：やむを得ない事由により本文ファイル非公開（2） 
論文名：A nationwide survey on tracheostomy for very-low-birth-weight infants in Japan.

（和訳日本における極低出生体重児の気管切開に関する全国調查）

区 分：乙

$$
\text { 論 文内容の要旨 }
$$

日本の極低出生体重児の気管切開の疫学と危険因子を明らか寸る目的で、2003 年から 2012 年までに周産期母子医療センターネットワークデータベースに登録された 40,806 人 の極低出生体重児を調査した。日齢 28 以降も生存した 34,674 人を対象とし、周産期情報、 NICU 入院中の合併症、および気管切開に関連する因子を分析した。気管切開を受けた極低

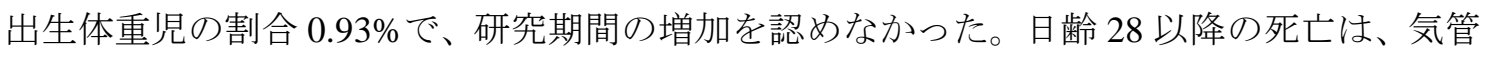
切開の有無で割合に有意差はなかった。気管切開を受けた児は、低酸素性虚血性脳症、筋 疾患、重症または中等症の気管支肺異形成、染色体異常、敗血症の合併症の割合が高かっ た。日本の極低出生体重児においては、気管切開術の割合に増加はなく、術後の死亡率は 低いことを示された。気管切開を減らすためには、極低出生体重児の呼吸器疾患や神経筋 疾患により手厚い治療が必要である。 